\title{
Assessment of Complications Associated with Various Anesthetic Techniques in Patients Undergoing Hip Replacement Surgeries: A Retrospective Study
}

\author{
Vivek Tyagi', Pramod Chand ${ }^{2}$, Navab Singh ${ }^{3}$ \\ ${ }^{1}$ Assistant Professor, Department of Anaesthesia, Mulayam Singh Yadav Medical College and Hospital, Naal Pur, Distt- Meerut, UP, Pin $245206,{ }^{2}$ Assistant \\ Professor, Department of Anaesthesia, L.L.R.M. Medical College, Meerut, $250004,{ }^{3}$ Associate Professor, Department of Anaesthesia, L.L.R.M. Medical \\ College, Meerut, 250004.
}

\section{Abstract}

Background: Hip fracture in the elderly is a very common fracture, which mainly requires surgical treatment. Hence; we planned the present study to assess various complications associated with various anesthetic techniques in patients undergoing hip replacement surgeries. Subjects and Methods: Analysis of data files of a total of 160 patients was done. Retrieval of complete demographic and clinical data of all the subjects included in the present study was done. Recording of following parameter was done: Form of anaesthetics technique, Surgical procedure duration, and Fluid type and amount administered. Complication of the results was done by SPSS software. Results: Most commonly observed complications observed in the present study were hypotension, bleeding, embolism and cardiac arrest. Non- significant results were obtained while comparing the occurrence of complications among different study groups. Conclusion: Various types of anaesthetics techniques can be used with equal effectiveness among patients undergoing Hip replacement surgery.

Keywords: Anesthetic, Complications, Hip replacement surgery.

Corresponding Author: Dr. Pramod Chand, Assistant Professor, Department of Anaesthesia, L.L.R.M. Medical College, Meerut, 250004

Received: April 2019

Accepted: May 2019

\section{Introduction}

Hip fracture in the elderly is a very common fracture, which mainly requires surgical treatment. ${ }^{[1]}$ This fracture is associated with various morbidity and mortality. Surgery for hip fracture is performed using either general anesthetic administration or neuraxial (spinal and epidural) method. Under general anesthesia, the patient becomes completely anesthetized by using injectable drugs or certain respiratory gases. ${ }^{[2-4]}$ In this method, the patient does not have the ability to breathe during anesthesia and the artificial respiratory machine is used to breathe. Recent studies on comparative effectiveness utilizing population based data have given us a novel insight on anesthetic practice and outcome, showing favorable results in the usage of regional vs. general anesthesia. ${ }^{[5,6]}$ Hence; under the light of above mentioned data, we planned the present study to assess various complications associated with various anesthetic techniques in patients undergoing hip replacement surgeries.

\section{Subjects and Methods}

The present study aimed for assessing the complications associated with various aesthetic techniques in patients undergoing hip replacement surgeries. For the present study, ethical clearance was obtained from the ethical committee of the institution. Analysis of data files of a total of 160 patients was done. Exclusion criteria for the present study included:

- Subjects in which follow-up records were missing,

- Subjects with presence of any form of co-morbid condition,

- Diabetic and hypertensive subjects

Retrieval of complete demographic and clinical data of all the subjects included in the present study was done. Recording of following parameter was done;

- Form of anaesthetics technique

- Surgical procedure duration,

- Fluid type and amount administered

Complication of the results was done by SPSS software. Chi square test was used for evaluation of level of significance.

\section{Results}

[Table 1 and Figure 1] show the demographic data. Mean age of the patients of the general anesthesia, combined spinal epidural anesthesia, Spinal, and Lumbar plexus block was 65.8 years, 66.8 years, 69.2 years and 63.3 years respectively. [Table 2 and Figure 2' show the complications. Most commonly observed complications observed in the present study were hypotension, bleeding, embolism and cardiac arrest. Non- significant results were obtained while 
comparing the occurrence of complications among different study groups.

\section{Table 1: Demographic data.}

\begin{tabular}{|c|c|c|c|c|c|}
\hline \multirow{2}{*}{$\begin{array}{l}\text { Type of } \\
\text { anesthesia }\end{array}$} & \multirow{2}{*}{$\begin{array}{l}\text { Number } \\
\text { of } \\
\text { subjects }\end{array}$} & \multirow{2}{*}{$\begin{array}{l}\text { Mean } \\
\text { age } \\
\text { (years) }\end{array}$} & \multicolumn{2}{|c|}{ Gender } & \multirow{2}{*}{$\begin{array}{l}\text { Mean } \\
\text { weight } \\
\text { (Kg) }\end{array}$} \\
\hline & & & Males & Female & \\
\hline $\begin{array}{l}\text { General } \\
\text { anesthesia }\end{array}$ & 40 & 65.8 & 25 & 15 & 66.8 \\
\hline $\begin{array}{l}\text { Combined } \\
\text { spinal } \\
\text { epidural } \\
\text { anesthesia }\end{array}$ & 40 & 66.8 & 29 & 11 & 70.2 \\
\hline Spinal & 40 & 69.2 & 26 & 14 & 64.8 \\
\hline $\begin{array}{l}\text { Lumbar } \\
\text { plexus block }\end{array}$ & 40 & 66.3 & 27 & 13 & 69.9 \\
\hline
\end{tabular}

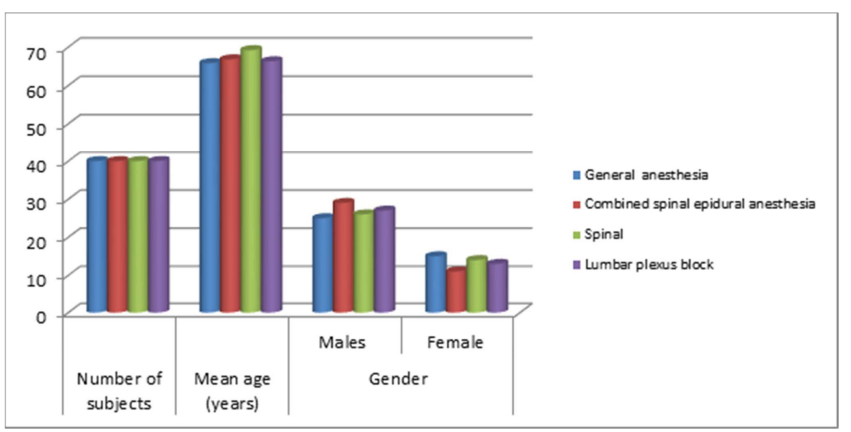

Figure 1: Demographic data

Table 2: Complications

\begin{tabular}{|c|c|c|c|c|c|c|c|c|}
\hline \multirow[t]{2}{*}{$\begin{array}{l}\text { Type of } \\
\text { anesthesia }\end{array}$} & \multicolumn{2}{|c|}{ Hypotension } & \multicolumn{2}{|c|}{ Bleeding } & \multicolumn{2}{|c|}{ Embolism } & \multicolumn{2}{|c|}{$\begin{array}{l}\text { Cardiac } \\
\text { arrest }\end{array}$} \\
\hline & $\mathrm{n}$ & $\%$ & $n$ & $\%$ & $\mathrm{n}$ & $\%$ & $\mathrm{n}$ & $\%$ \\
\hline $\begin{array}{l}\text { General } \\
\text { anesthesia }\end{array}$ & 15 & 10 & 8 & 5.33 & 5 & 3.33 & 2 & 1.34 \\
\hline $\begin{array}{l}\text { Combined } \\
\text { spinal } \\
\text { epidural } \\
\text { anesthesia }\end{array}$ & 10 & 6.67 & 7 & 4.67 & 4 & 2.67 & 1 & 0.67 \\
\hline Spinal & 8 & 5.33 & 10 & 6.67 & 6 & 4 & 2 & 1.34 \\
\hline $\begin{array}{l}\text { Lumbar } \\
\text { plexus } \\
\text { block }\end{array}$ & 11 & 7.33 & 9 & 6 & 4 & 2.67 & 1 & 0.67 \\
\hline p- value & \multicolumn{2}{|c|}{0.58} & \multicolumn{2}{|c|}{0.81} & \multicolumn{2}{|c|}{0.77} & \multicolumn{2}{|c|}{0.36} \\
\hline
\end{tabular}

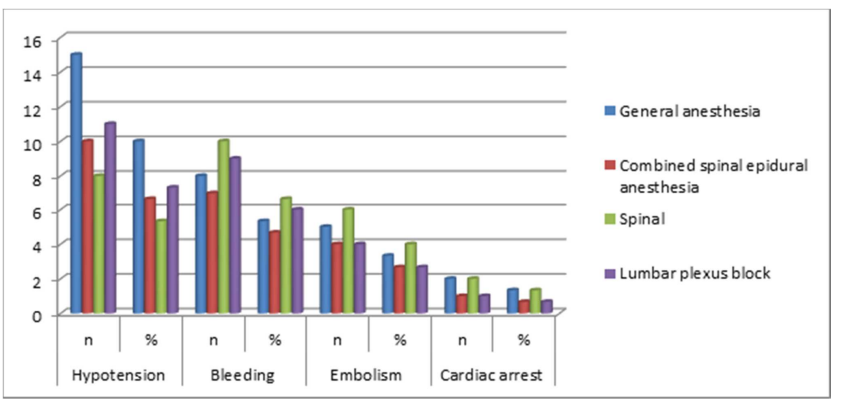

Figure 2: Complications

\section{Discussion}

The increasing demand for hip arthroplasties over the last decades has sparked the creation of new and innovative anesthetic techniques and analgesic pathways with the goal to support best possible outcomes among this frequently elderly patient population. As a result, today different perioperative treatment pathways are available to physicians and their patients. In this context, the focus has shifted to techniques based on regional anesthetic and analgesic techniques. This trajectory has been fueled by a number of advantages including effective, long-lasting and focused pain control, decreased need for systemic analgesics and earlier mobilization. ${ }^{[5-7]}$

Total hip replacement is procedure characterized by great perioperative disturbances including cardiovascular complications, high incidence of thromboembolic complications, possible significant perioperative blood loss, possible bone cement effect and high level of postoperative pain. Anesthetic assessment of patients include preoperative preparations, intraoperative and postoperative care. ${ }^{[8-10]}$

[Table 1] shows the demographic data. Mean age of the patients of the general anesthesia, combined spinal epidural anesthesia, Spinal, and Lumbar plexus block was 65.8 years, 66.8 years, 69.2 years and 63.3 years respectively. Alecci V et al compared the efficacy of the minimally invasive direct anterior approach and the standard lateral approach to total hip replacement surgery by observing intra- and perioperative outcomes. The authors conducted a retrospective study on a group of 419 consecutive patients undergoing total hip replacement for coxarthrosis. The patients were divided into a first group (A) of 198 patients who had surgery with the standard lateral approach, and a second control group (B) of 221 patients who had the same procedure via the minimally invasive direct anterior approach. Assessment of the two groups considered the following perioperative parameters: length of the surgical procedure, intraoperative complications, intra- and postoperative blood loss, postoperative pain, postoperative nausea and vomiting, length of stay, and type of discharge. The two groups were homogeneous when compared in relation to mean age, sex and body weight. The minimally invasive direct anterior approach was performed within an acceptable time $(89 \pm 19 \mathrm{~min}$ vs. $81 \pm 15 \mathrm{~min})$ and with modest blood loss $(3.1 \pm 0.9 \mathrm{~g} / \mathrm{dL}$ vs. $3,5 \pm 1 \mathrm{~g} / \mathrm{dL})$. Patients experienced less pain $(1.4 \pm 1.5 \mathrm{NRS}$ score vs. $2.5 \pm 2 \mathrm{NRS}$ score), and PONV affected only 5\% versus $10 \%$ of cases. Times to discharge were shorter $(7 \pm 2$ days vs. $10 \pm 3.5$ days), and $58.4 \%$ versus $11.6 \%$ of patients were discharged to home. In their study, patients treated with a minimally invasive direct anterior approach had a better perioperative outcome than patients treated with the lateral approach. ${ }^{[10]}$

Most commonly observed complications observed in the present study were hypotension, bleeding, embolism and cardiac arrest. Non- significant results were obtained while comparing the occurrence of complications among different study groups. Koç $\mathrm{M}$ et al identified surgical and anaesthetic methods applied, intraoperative hemodynamic changes, length of stay in the post-anaesthesia care unit, and postoperative complications. Demographic characteristics, co-morbidities, preoperative laboratory findings, intraoperative findings, and admission or refusal to the intensive care unit of patients who underwent hip replacement surgery between January 2008-December 2010 were enrolled. Out of 500 patients, 33.4\% $(n=164)$ were operated under general anaesthesia, 34\% ( $n=170)$ under combined spinal-epidural anaesthesia, $22.2 \%(\mathrm{n}=111)$ under spinal anaesthesia, $6.4 \% \quad(n=32)$ under combined lomber 
plexus block and sciatic nerve block, and $4 \%(n=20)$ under epidural anaesthesia. Mean hospital stay was 7 days in the general anaesthesia group and 5 days in the regional anaesthesia group. American Society of Anesthesiologists (ASA) scores and incidence of co-morbidities were higher in the partial hip replacement group. ${ }^{[1]}$

\section{Conclusion}

Under the light of above obtained data, the authors conclude that various types of anaesthetics techniques can be used with equal effectiveness among patients undergoing Hip replacement surgery.

\section{References}

1. Modig J, Borg T, Karlstrom G, Maripuu E, Sahlstedt B. Thromboembolism after total hip replacement: role of epidural and general anesthesia. Anesth Analg. 1983;62:174-80.

2. Indelli PF, Grant SA, Nielsen K, Vail TP. Regional anesthesia in hip surgery. Clin Orthop Relat Res. 2005;441:250-5.

3. Pugely AJ, Martin CT, Gao Y, Mendoza-Lattes S, Callaghan JJ. Differences in short-term complications between spinal and general anesthesia for primary total knee arthroplasty. J Bone Joint Surg Am.
2013;95:193-9.

4. Geerts WH, Heit JA, Clagett GP. Prevention of venous thromboembolism. Chest. 2001;119:132-75.

5. Salvati EA, Pellegrini JR, VD, Sharrock NE. Symposium-Recent advances in venous thromboembolic prophylaxis during and after total hip replacement. J Bone Joint Surg. 2000;82-A:252-66.

6. Rashiq S, Finegan BA. The effect of spinal anesthesia on blood transfusion rate in total joint arthroplasty. Can J Surg. 2006;49:391-6.

7. Davis FM, Laurenson VG, Gillespie WJ, Wells JE, Foate J, Newman E. Deep vein thrombosis after total hip replacement: a comparison between spinal and general anaesthesia. J Bone Joint Surg Br. 1989;71:181-5.

8. Lessire H, Pfisterer M, Schweppe-Hartenauer ML, Puchstein C. Hemodynamic effects of a combination of general and peridural anesthesia during anesthesia induction in geriatric patients. Anaesthesist. 1991;40:375-9.

9. Neuman MD, Silber JH, Elkassabany NM, Ludwig JM, Fleisher LA. Comparative effectiveness of regional versus general anesthesia for hip fracture surgery in adults. Anesthesiology. 2012;117:72-92.

10. Alecci V, Valente M, Crucil M, Minerva M, Pellegrino CM, Sabbadini DD. Comparison of primary total hip replacements performed with a direct anterior approach versus the standard lateral approach: perioperative findings. J Orthop Traumatol. 2011;12(3):123-129. doi:10.1007/s10195-011-0144-0

11. Koç M, Saçan Ö, Gamlı M, et al. Retrospective Evaluation of Anaesthesia Techniques for Hip Replacement Operations. Turk J $\begin{array}{lll}\text { Anaesthesiol } & \text { Reanim. }\end{array}$ doi:10.5152/TJAR.2014.07108

Copyright: ( $)$ the author(s), publisher. Academia Anesthesiologica International is an Official Publication of "Society for Health Care \& Research Development". It is an open-access article distributed under the terms of the Creative Commons Attribution Non-Commercial License, which permits unrestricted non-commercial use, distribution, and reproduction in any medium, provided the original work is properly cited.

How to cite this article: Tyagi V, Chand P, Singh N. Assessment of Complications Associated with Various Anesthetic Techniques in Patients Undergoing Hip Replacement Surgeries: A Retrospective Study. Acad. Anesthesiol. Int. 2019;4(1):112-114.

DOI: dx.doi.org/10.21276/aan.2019.4.1.26

Source of Support: Nil, Conflict of Interest: None declared. 